\title{
THE ANALYSIS OF ADVERB SELECTION IN ENGLISH APPLICATION LETTER FOR BUSINESS CORRESPONDENCE
}

\author{
SURYA KELANA PUTRA \\ Universitas Prima
}

\begin{abstract}
Dunia bisnis adalah dunia yang sangat berkembang dalam kehidupan manusia saat ini. Perkembangan yang pesat inilah yang membuat manusia memiliki lapangan pekerjaan yang cukup beragam. Dan salah satu surat yang sangat penting dan memiliki hubungan yang sangat erat dengan dunia bisnis adalah surat lamaran pekerjaan. Surat ini merupakan langkah awal untuk membuat pertemuan antara satu instansi yang berperan sebagai targetdengan pihak pelamar yang berperan sebagai penulis surat yang akan berujung pada sebuah kesepakatan hubungan kerja. Adapun dalam penulisan surat ini tentu meliputi penggunaan dan pemilihan adverb atau kata keterangan yang penggunaannya dipengaruhi oleh konteks situasi.

Keywords: Bisnis, Kata Keterangan (Adverb), Konteks Situasi
\end{abstract}

\section{INTRODUCTION}

Business is one of the most rapidly growing areas in human life today. Business has become very important since it has been developed from a simple activity as barter into more complex activities. Business correspondence is one part that cannot be separated from the process of doing business activities. The myth about business correspondence is that it must be formal and standardized. One of the business letters is the Application Letter. Application letters can be written in response to an advertisement in the newspaper or on the Net. The structures of the letter was also affected by the adverbs such as adverb of time, adverb of place, adverb of manner, adverb of frequency and adverb of degree (Bhatia, V.K. (1993). Analyzing genre: Language use in professional settings. London \& New York: Longman).

This writing entitled as Adverb Selection in English Application Letter for Business Correspondence, considering the word 'adverb selection' which derived from the word 'adverb' meaning 'verb modifier' (Hornby, 1987:32) and the word 'selection' meaning 'an act of choosing between two or more possibilities' (Hornby, 1995:773). So it can be inferred that the term adverb selection refers to an act of choosing between two or more possibilities of particular adverb of a language.

Regarding to the features above the adverb selection is being applied in business correspondence. The problems discussed in this study, are as follows:

1. What adverbs are found in English application letter for business correspondence to develop a good writing skill?

2. How does the context of situation proposed by Halliday and Hasan affect adverb selection in English application letter for business correspondence? 
Generally, this study is proposed to complete a fulfillment to obtain the Sarjana Sastra degree at the English Department, Faculty of Letters, Udayana University as well as to improve my knowledge and skills in English, especially in writing and composing a study for academic purpose. Specifically, this study aims to find out and analyze the adverbs which are found in English application letter for business correspondence, and to see how the context of situation affects the adverb selection in English application letter for business correspondence.

\section{RESEARCH METHOD}

The methodology of this study covers three points, namely where the data were taken as the data source, how the data were collected, and how the data was analyzed. Along with the use of corpus analysis software AntConc 3.2.4 (a freeware corpus analysis toolkit Developed by Laurence Anthony Faculty of Science and Engineering Waseda University, Japan) to find and analyze adverb selection in business correspondence in term of frequency, the library research methods were used for this writing with context of situation theory from Halliday and Hasan in their book entitled Language, context and text: aspect of language in a social semiotic perspective (Deakin University, London, 1985).

\section{ANALYSIS}

Application letter is one of the most important letters for business correspondence, it is used to apply for a job, to express the will, and show the quality of writers to attract the riders for getting a job. The analysis was presented into two parts. First, the finding of special words which are conveyed in English application letter for business correspondence in one word class: adverb. Second, the adverb selection that was analyzed based on context of situation in term of field of discourse, tenor of discourse and mode of discourse based on theory from Halliday and Hasan in their book entitled Language, context and text: aspect of language in a social semiotic perspective (Deakin University, London, 1985).

\section{Application Letter \\ 10 Baker Street \\ Cleveland, Ohio 40613 \\ Phone: (216) 223-555 \\ March 20, 2005 \\ Mr. Christopher Miller \\ Personnel Manager \\ Ohio Chem. Corporation}

Dear Mr. Miller:

I am replying to your advertisement in the Newspaper in February issue of Cosmetic Chemistry that I often read. 
My work with Basic Pharmaceutical's Anesthetic and Analgesic Division consisted primarily of developing and testing non-oleaginous bases for tropical anesthetics. The bases, of course, had to be broadly anti-allergic if they were to be of commercial value and were tested for the same. Our procedures, in both development and testing, were similar to those used in the cosmetic industry, and our tests were at least as rigorous. My resume also shows, as your ad requested heavy quantitative analysis and quality control experience and I am very interesting. We should speak further; I will be in New York for the Pharmaceutical Chemists' Society meeting next month. When can we arrange an interview for that time? Thank you for your consideration. Yours truly,

\section{Paul Thompson}

From the application letters above, using the AntConc 3.2 program the adverb lists were found: adverbs of time such as: in February, next week etc.; adverbs of place such as: in advertisement, in New York, etc.; adverbs of manner such as: primarily, softly, slowly, etc.; adverbs of degree such as: very and adverbs of frequency such as: often, seldom, etc. These adverbs are listed as bellow:

\section{Adverb of Time}

\begin{tabular}{|l|l|}
\hline Adverb & Frequency \\
\hline In February & 1 \\
\hline Next month & 1 \\
\hline
\end{tabular}

2. Adverb of Place

\begin{tabular}{|l|l|}
\hline Adverb & Frequency \\
\hline In the Newspaper & 1 \\
\hline & \\
\hline
\end{tabular}

\begin{tabular}{|l|l|}
\hline In New York & 1 \\
\hline
\end{tabular}

\section{Adverb of Manner}

\begin{tabular}{|l|l|}
\hline Adverb & Frequency \\
\hline Primarily & 1 \\
\hline Broadly & 1 \\
\hline Truly & 1 \\
\hline
\end{tabular}

\section{Adverb of frequency}

\begin{tabular}{|l|l|}
\hline Adverb & Frequency \\
\hline Often & 1 \\
\hline
\end{tabular}

\section{Adverb of degree}

\begin{tabular}{|l|l|}
\hline Adverb & Frequency \\
\hline Very & 1 \\
\hline
\end{tabular}




\section{Context of situation analysis}

As seen in the data, the adverb (adverb of place) "in the News paper", was used by the writer. This list of adverb had a related meaning of business term. The adverbs which indicated the term of business was shown by where the data were taken. The data showed that the use of adverb (adverb of manner) "truly" was used in closing the letters. It was usually used as a formula for closing a formal letter or business style especially for application letter.

\section{Field of Discourse.}

This application letter showed that the letter was written to give the information about the quality of writer and explained about the interest in geting the job which was advertised in newspaper. It was shown by using of adverb "often" to express his desire for further action in business relationship.

\section{Tenor of discourse}

As the three elements of tenor:

1. The roles played by participants are: the writer was the person who gave the information about himself and asked the opportunity to make a further business relationship. The writer was the person who had not yet met with the readers before.

2. From its word choice (adverb), the text indicates a formality; the letter contains the information of writer and the adverbs were used for specifications of time, place, manner, degree and frequency. 3. The focus: it is focused on the promotion and description about the writer's potential and benefits which are provided to the readers. The further reactions are required by the writer to be done by the reader.

\section{Mode of discourse}

The mode of the letter was written to be read by the target reader. The letter was dedicated to specific person or people in a company with whom the writer had not been made business relationship before.

\section{CONCLUSIONS}

The adverb selection in English application letter for business correspondence in terms of frequency which are related to business words were very low in actual frequency compared to the most frequent lexical items. The contact of situation which was purposed by Halliday and Hassan was significantly affecting the adverb choice in English application letter for business correspondence, this was remarkably homogenous in nature, and can be encapsulated to a high degree within a limited number of semantic categories. The adverb selection in English application letter in business correspondence was influenced by the field of discourse, tenor of discourse and mode of discourse 


\section{REFERENCES}

Connor, U., Davis, K., \& De Rycker, T. (1995). Correctness and clarity in applying for overseas jobs: A cross-cultural analysis of US and Flemish applications. TEXT 15 (4), 457-475.

Halliday, M.A.K and Hasan, R. 1985. Context and Text; Aspect of Language in A social-Semiotic Perspective. London: Deakin University Press

Ji-yu. 2007. Genre analysis on business English correspondence

Norman et.al. 1983. Writing Skills. A problem-solving approach. Cambridge University Press,. Chapter 2, Formal letter I.

Williams, Milburn et.al. 1961. First Course In College English. The Riverside Press. Boston. 